\title{
Evaluation of the Cornell Net Carbohydrate and Protein System model on the prediction of dry matter intake and milk production of grazing crossbred cows $^{1}$
}

\author{
Mirton José Frota Morenz ${ }^{2}$, José Fernando Coelho da Silva ${ }^{3}$, Luiz Januário Magalhães \\ Aroeira $^{2}$, Fermino Deresz ${ }^{2}$, Hernán Maldonado Vásquez ${ }^{3}$, Fernando César Ferraz Lopes ${ }^{2}$, \\ Domingos Sávio Campos Paciullo², Luis Orlindo Tedeschi ${ }^{4}$
}

\footnotetext{
1 Projeto financiado pelo CNPq e FAPEMIG

2 Embrapa Gado de Leite.

${ }^{3}$ Universidade Estadual do Norte Fluminense.

${ }^{4}$ Texas A\&M University.
}

ABSTRACT - The Cornel Net Carbohydrate and Protein System model version 5.0 was assessed as for its prediction of dry matter intake and milk production of grazing lactating Holstein $\times$ Zebu cows. Eight lactating cows grazing elephant grass (Pennisetum purpureum, Schum., cv. Napier) were used in two experiments of 30 days each. The experimental design was of randomized blocks (subplots). Dry matter intake was estimated using the chromium oxide and in vitro dry matter digestibility techniques. The estimated dry matter intake was compared with the values predicted by the model. Extrusa samples of the elephant grass pasture were obtained from a cow with esophageal fistula during nine days in each experimental period. Carbohydrate and nitrogenous fractions were analyzed and the degradation rate of carbohydrate was estimated by the gas production technique. The inputs referring to the animals (body weight, age, milk production, milk composition and breed type), to the environment (temperature, relative humidity of air and management condition) and to feeds chemical composition in each experimental period were inserted in the model. The model was accurate on the prediction of dry matter intake, considering that the mean values obtained by the chromium oxide technique and predicted by model $(2.45$ and $2.46 \%$ of body weight, respectively) did not differ significantly from each other. However, the model underestimated the observed milk production in $62.4 \%$, where the metabolizable energy was the first limiting. These results demonstrate the need for studies that provide the development of a database for tropical foods (chemical composition and dynamics of rumen fermentation) and fitting of the model to the tropical conditions, for its appropriate application in formulation of diets and supplements in these regions.

Key Words: chromium oxide, elephant grass, lactating cows, rotational stocking

\section{Introduction}

Nutritional requirement systems, such as the Cornell Net Carbohydrate and Protein System (CNCPS; Fox et al., 2004) and the NRC (2001) consider the data of the food chemical composition, rumen degradation parameters, intestinal digestibility of the nitrogenous and carbohydrates fractions, specific adjustments to the bred parameters, animal category, production level, and the interaction of these variables with climatic conditions and management (Tedeschi et al., 2005), in order to formulate balanced diets and/or develop supplementation strategies.

The CNCPS model has been used for over 20 years and, like most systems, was designed using the nutritional requirements of specialized European breeds, reared under controlled conditions and fed food from temperate climates. This model uses mechanistic and empirical relationships in the nutritional diagnosis to formulate and evaluate cattle diets (Fox et al., 1995). From the nutritional characteristics of the dietary ingredients and their interactions with the animal requirements and management practices, the model allows the prediction of the cattle performance under different conditions of production.

However, although the CNCPS contains a biological and mechanistic structure, which theoretically allows its application in various environmental conditions and management systems, with different breeds and feeds, the application in tropical conditions must be evaluated before recommending the use of this model in the tropical production systems (Molina et al., 2004), where breeds, food and management are, in most cases, different from those found in temperate regions.

Therefore, the model application in tropical conditions requires prior evaluation and possible adjustments for 
optimization, particularly regarding the characterization of nitrogenous and carbohydrate fractions of tropical forages and respective degradation rates. Fox et al. (2000) reported the lack of information regarding tropical foods, suggesting the development of research in this area, to update and enable the use of more reliable tropical feeds database to the CNCPS predictions.

Given the above, this study aimed to evaluate the CNCPS model version 5.0 in the prediction of dry matter intake and milk production in grazing Holstein $\times$ Zebu cows under tropical conditions.

\section{Material and Methods}

The experiment was carried out during March to April 2002, at the Centro Experimental José Henrique Bruschi, belonging to Embrapa Gado de Leite, situated at the Zona da Mata, Minas Gerais.

The CNCPS model, version 5.0 (level 2), was evaluated on the prediction of the dry matter intake (DMI) and milk production of grazing crossbred lactating cows. The "level 2 " of the CNCPS model considers the effects of rumen fermentation, using the rumen submodel in the predictions. The program inputs concerning animals (weight, body condition score, age, milk production and composition, breed type, etc.), environment (temperature, air relative humidity, management, etc.) (Table 1) and forage chemical composition (Table 2) were obtained in each evaluation period.

Eight Holstein $\times$ Zebu cows were used in two periods (March and April). Animals were weighed before and after each experimental period and mechanically milked twice daily (06:00 and 14:00 hours). Average milk productions were $10.5 \pm 2.6 \mathrm{~kg} /$ day and $9.7 \pm 2.5 \mathrm{~kg} /$ day for the first and second experimental periods, respectively. During the experimental period, milk samples $(50 \mathrm{~mL})$ were collected from each animal every 15 days, when $2 / 3$ and $1 / 3$ were sampled in morning and evening milking, respectively, with the objective of obtaining representative samples of the daily milk production. Milk samples were placed in vials containing preservative bronopol, and sent to laboratory for determination of protein and fat content (AOAC, 1990).

Animals were managed on elephant grass pasture under rotational stocking, with 30 days of rest and three days of paddock occupation, receiving mineral salt. The pasture stocking rate was, approximately, 4.5 cows/ha.

The forage mass above the residual height was estimated in each experimental period, according to methodology described by Cóser et al. (2003): one day before the start of grazing in the paddocks, three clumps of elephant grass representative of those found in the paddocks were selected, corresponding to the clumps with high, medium and low forage production. Samples were collected manually, where all the structures above the residual height (leaves and tender stems) were collected, weighed and taken to the oven for determination of dry matter (DM) content. The mean value of dry weight of the three clumps, multiplied by the number of plants per $49 \mathrm{~m}^{2}$ of each paddock, was used to estimate the forage production ( $\mathrm{kg} / \mathrm{ha}$ of $\mathrm{DM}$ ) and forage allowance (kg/animal/day of DM).

Table 1 - Inputs descriptions applied to evaluate the Cornell Net Carbohydrate and Protein System model at the prediction of dry matter intake and milk production

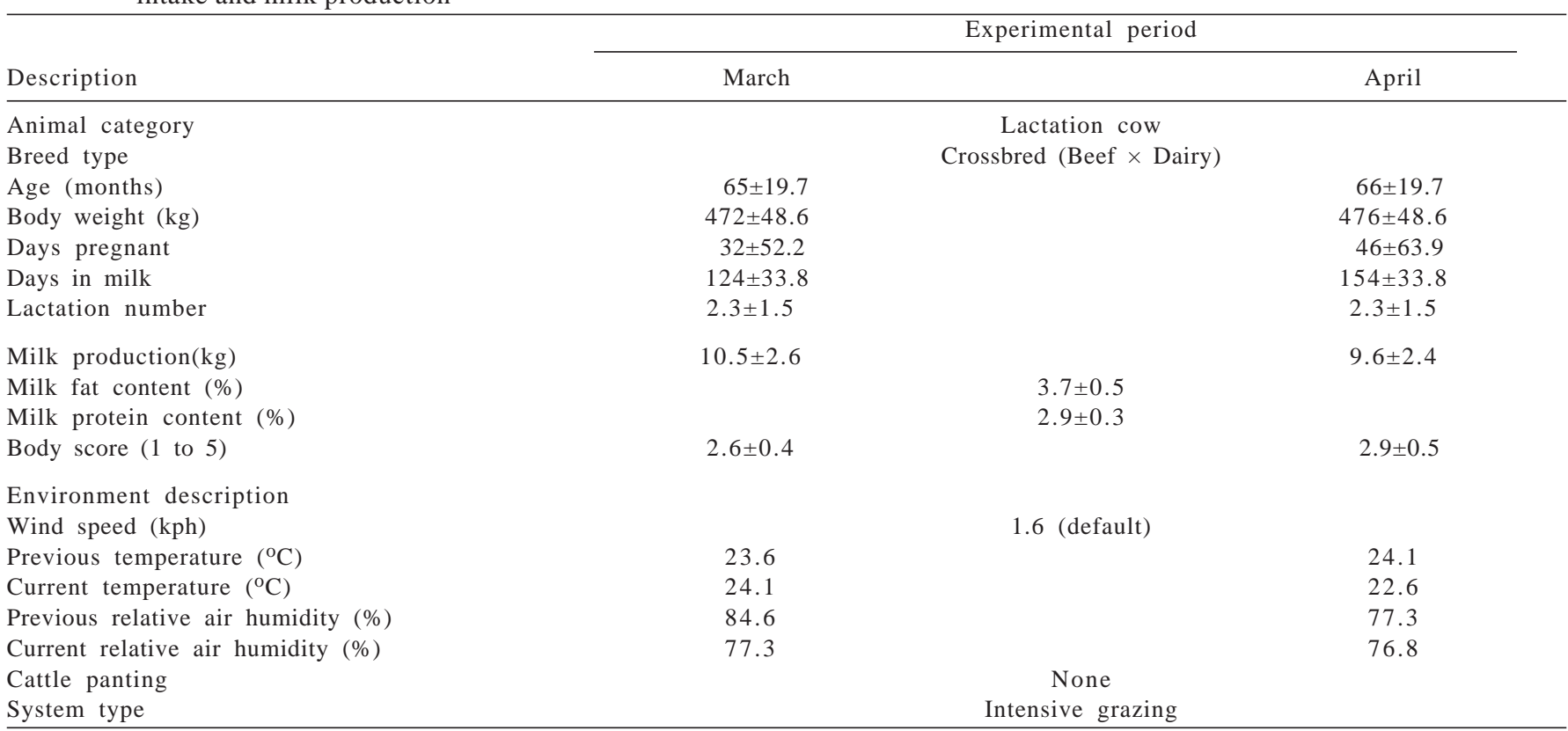


Extrusa samples were collected in a bag fitted with hard plastic screen on the bottom to facilitate drainage of saliva. For the collections, a Holstein $\times$ Zebu cow (weighing $540 \mathrm{~kg}$ ) provided with esophageal fistula and fasted for 12 hours (Van Dyne \& Torrel, 1964) was used.

Extrusa samples were collected for nine consecutive days on the first, second and third days of paddock occupation, in each of the three paddocks and in each period, during 30 minutes of grazing every morning. Samples were identified and frozen at $18^{\circ} \mathrm{C}$ immediately after collection. At the end of the experiment, samples were thawed and dried in forced ventilation oven $\left(60 \pm 5^{\circ} \mathrm{C} ; 72\right.$ hours). Subsequently, samples were ground in a Wiley mill, with sieves of $1 \mathrm{~mm}$. Chemical analysis were performed according to AOAC (1990), for determination of dry matter at $105^{\circ} \mathrm{C}$, total nitrogen, ether extract and ash; and Van Soest et al. (1991), for determination of cell wall components (neutral and acid detergent fiber and lignin). For the in vitro estimates of DM digestibility (IVDMD) (Tilley \& Terry, 1963) and rates of digestion of carbohydrates (Pell \& Schofield, 1993), a composite sample constituted by first, second and third days of each paddock (repeat), representative of each period was used.

The estimate of DMI was done by chromium oxide $\left(\mathrm{Cr}_{2} \mathrm{O}_{3}\right)$ methodology associated to IVDMD (Pond et al., 1989), and used to obtain the milk production values predicted by the CNCPS. Animals received 10.0 grams of $\mathrm{Cr}_{2} \mathrm{O}_{3}$, dosed at 5.0 grams, twice daily (07:30 and 14:30 hours), orally. The procedure lasted 14 days: the first five days for obtaining the balance of intake and excretion of the indicator, and the fecal samples taken during the last nine days.

Fecal samples were collected directly from the rectum of the animals, for nine days, twice daily (07:30 and 14:30 hours), identified and frozen at $-18{ }^{\circ} \mathrm{C}$. At the end of the experiment, samples were thawed and dried in forced ventilation oven ( $60 \pm 5^{\circ} \mathrm{C} ; 72$ hours). Subsequently, samples were ground in a Wiley mill with 1-mm sieve and analyzed for DM. The DMI was estimated using the relationship between fecal output and IVDMD (Pond et al., 1989).

The estimate of rumen passage rate of the solid phase was performed ten days after the period of estimating forage intake. 70 grams of NDF - chromium-mordant packed in gelatin capsules were administrated orally to each animal (single dose). Three Holstein $\times$ Zebu cows representative of the group where DMI was estimated by $\mathrm{Cr}_{2} \mathrm{O}_{3}$ /IVDMD methodology - grazing on elephant grass cv. Napier, managed under a rotational stoking, with three days of paddock occupation and 30 days of rest to estimate rumen passage were used. Samples of feces were collected

Table 2 - Mean values for chemical composition, nitrogen and carbohydrate fractions of the elephant grass and respective digestion rates

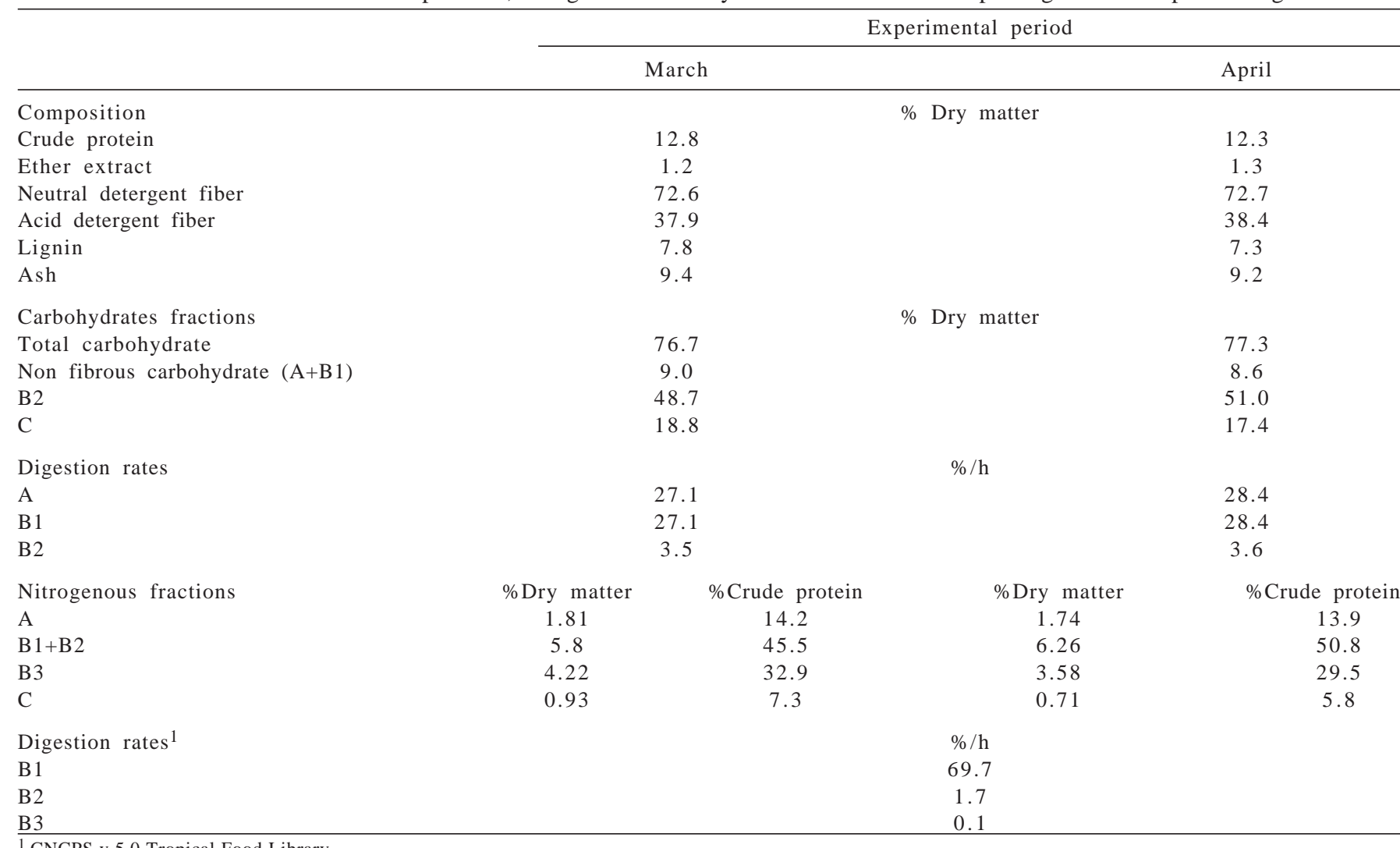


at the following times after marker infusion: $0,8,16,24,28$, 32 , 36, 40, 44, 48, 52, 56, 60, 64, 72, 80, 88, 100, 112, 124, and 148 hours.

The chromium content in feces was determined by atomic absorption spectrophotometry, using the methodology described by Williams et al. (1962).

The kinetic parameters of the digestive tract were estimated by fitting the exponential model proposed by Grovum \& Williams (1973) to the data concerning the fecal marker, using the iterative Marquardt algorithm, by nonlinear regression procedure PROC NLIN (SAS, 2003).

Nitrogenous fractions were determined according with the protocol described by Licitra et al. (1996), with modifications, where the nitrogenous fractions B1 and B2 were not separated (expressed as B1+B2), due to the low levels of $\mathrm{B} 1$ fraction in tropical grasses. The $\mathrm{N}$ determination was done according to the methodology of Kjeldahl (AOAC, 1990), with application of correction factor 6.25 for conversion into crude protein.

Total carbohydrate (TC) and fractions corresponding to the non fibrous carbohydrates (NFC), B2 and C were calculated according to Sniffen et al. (1992). The digestion rates of carbohydrate fractions (NFC and B2) were estimated using the gas production technique (Pell \& Schofield, 1993). Cumulative gas production kinetics was estimated employing the logistic bicompartmental model (Schofield et al., 1994), using the iterative Marquadt algorithm, implemented in statistical software SAS (2003).

The digestion rate of the nitrogenous fractions, the amino acids and minerals contents, as well as the intestinal digestibility of nitrogenous and carbohydrate fractions were originated from napier grass - "Napiergrass (Pennisetum purpureum) Fresh, Brazil Long” - provided by CNCPS Tropical Food Library.

Model predictions were evaluated for accuracy and precision by comparing predicted and observed data (dry matter intake and milk production), according to methodology described by Tedeschi et al. (2000).

Mean bias, mean square prediction error (MSPE), and statistical measures of model performance were calculated as described by Tedeschi et al. (2000). Model performance was also evaluated using the regression analysis between observed $(\mathrm{Y})$ and predicted $(\mathrm{X})$ values. When the coefficient or linear intercept (B0) was not statistically different from zero in the regular regression, the slope of regression was forced through the origin. Regression through the origin is a regression in which the intercept is set to be zero and only the slope is parameterized. The slope, obtained when the regression was forced through the origin $(\mathrm{B} 0=0)$, minus 1 , is considered the tendency of the model to under or overestimate the observed variable. However, when the intercept (B0) of the regular regression did not differ from zero $(P<0.05)$, the tendency of the model was calculated by dividing the mean difference of the variable $X$ and $Y$, by the average of variable $X$. The use of $R^{2}$ as well as other statistics such as the residuals derived from the regression through the origin for comparison purposes is not recommended (Tedeschi et al., 2000; Tedeschi, 2006).

Another approach to evaluate the model adequacy was to determine the proportion of deviation points (CNCPS model-predicted minus observed) that lie within acceptable limits (Mitchell \& Sheehy, 1997). Limits of 0.13 and $0.13 \%$ live weight for DMI and -1.2 and $1.2 \mathrm{~kg} /$ day for MP comparisons were established. This range represents the values delimiting a 95\% confidence interval of the DMI and milk production means, observed in the experiment.

The statistical analyses were performed using the SAS statistical package (Statistical Analysis System, version 9.0). The parameters of the regular regressions were obtained using PROC REG. Regression through the origin was obtained by the "NO INT" procedure in PROC REG. The mean deviation (MD) and the parameters of the regression equations were tested using the t-test $(\alpha=0.05)$.

\section{Results and Discussion}

There was no difference $(\mathrm{P}>0.05)$ between the dry matter intake values predicted by model and those obtained by the by the $\mathrm{Cr}_{2} \mathrm{O}_{3}$ /IVDMD technique (Table 3 ). The value observed for the mean bias $(0.01 \%$ or $0.06 \mathrm{~kg}$ BW/day DM) revealed the model accuracy in DMI prediction, which is confirmed by the low root mean square prediction error (RMSPE).

The parameters of the regression (intercept and slope) did not differ $(\mathrm{P}>0.05)$ from zero and 1 , respectively, by the Student t-test. Them, a new slope was estimated with the regression through the origin (intercept $=0$ ) $($ Table 3$)$. The regression also showed the model accuracy in DMI prediction, with slope and trajectory very similar to the ideal straight line $(\mathrm{X}=\mathrm{Y})$ (Figure 1).

For the perfect fit of the model, it is desirable to get the characteristics accuracy and precision. However, both measures are independent, and a precise method does not guarantee accuracy, nor vice versa. Thus, the accuracy can be considered the most important feature, since it measures the ability of the model of predicting actual values (Tedeschi et al., 2000; Tedeschi, 2006).

The observed results are consistent with Cappelle et al. (2001), Gesualdi Júnior et al. (2005) and Elyas et al. (2009), who reported the CNCPS model efficiency on DMI prediction 
under Brazilian conditions. The model tended to overestimate the DMI, according to the results reported by Gesualdi. Júnior et al. (2005). However, the results did not agree with those reported by Kolver et al. (1998), Tedeschi et al. (2000), Cappelle et al. (2001) or Molina et al. (2004), who observed the tendency of the model to underestimate DMI measured or estimated by indirect method.

However, when the deviations (difference between estimated values and those predicted by CNCPS) (Figure 2) were analyzed, the proportion of points within the acceptable range was only $31.25 \%$, which can be interpreted as inadequacy of the model in the prediction of this variable, characterized by low precision.

Zhao et al. (2008), evaluating the CNCPS model v.5.0, did not report difference $(\mathrm{P}>0.05)$ for mean bias, and observed low values for the RMSEP, indicating accuracy and precision of the model, respectively, on DMI prediction in beef cattle production systems in China.

Molina et al. (2004) evaluated the CNCPS model (using the equation proposed by Traxler, 1997) to estimate the
DMI. The authors reported that the CNCPS was efficient to estimate the DMI by lactating Holstein cows fed Tobiatã grass (Panicum maximum cv. Tobiatã) and concentrated ration, in feedlot. According to the authors, the good fit of the equation was expected under these experimental conditions, considering that the equation proposed by Traxler (1997), although developed in tropical weather conditions, used straightbred cows, mainly Holstein, managed in free stall and fed high levels of concentrate. However, the same authors, assessing the model for predicting DMI of lactating grazing crossbred cows (double-purpose), did not observe the same model accuracy on prediction. The authors pointed out that CNCPS tended to underestimate DMI, which was obtained with the technique of n-alkanes (C31, C32 and C33:C32). The authors attributed the lower model accuracy under these conditions, considering that the equation proposed by Traxler (1997), was developed based on results obtained using straightbred cows, reared in feedlot and fed concentrate, as described above.

Table 3 - Comparison between mean values of dry matter intake estimated by chromium oxide technique and predicted by model

\begin{tabular}{|c|c|c|c|c|}
\hline & Dry matter intake (\%BW) & Mean bias (\%BW) & Mean bias (\% predicted) & Standard deviation or $\mathrm{RMSPE}^{3}$ \\
\hline $\mathrm{Cr}_{2} \mathrm{O}_{3}{ }^{1}$ & 2.45 & 0.01 & 0.41 & 0.31 \\
\hline \multicolumn{5}{|c|}{ Regression $^{4}$} \\
\hline & Intercept & Slope & $\mathrm{R}^{2}$ & $\mathrm{P}$ \\
\hline Regular & -0.652 & 1.259 & 0.55 & 0.001 \\
\hline Origin $^{5}$ & - & 0.996 & 0.99 & $<0.001$ \\
\hline
\end{tabular}

${ }^{1}$ Dry matter intake estimated by chromium oxide technique.

2 Dry matter intake predicted by CNCPS v.5.0.

3 Standart deviation for estimated values $\left(\mathrm{Cr}_{2} \mathrm{O}_{3}\right)$ and root mean square prediction error (RMSPE) for predicted values (CNCPS).

${ }^{4}$ The estimated parameters of regression, intercept and slope, were evaluated by t-test $(0.05)$, for $\mathrm{B}_{0}=0$ and $\mathrm{B}_{1}=1$.

${ }^{5}$ Regression through the origin $\left(\mathrm{B}_{0}=0\right)$.

BW - body weight.

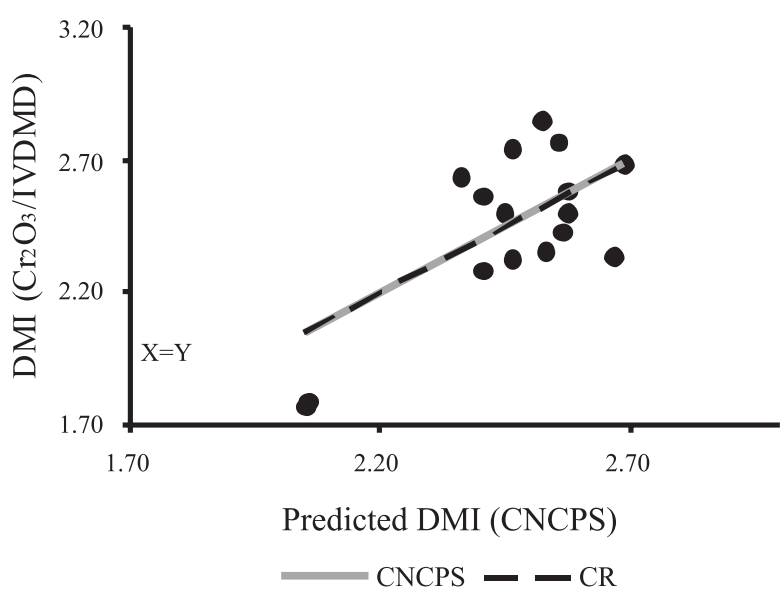

Figure 1 - Relationship between dry matter intake values (\%BW) estimated by chromium oxide technique and predicted by model.

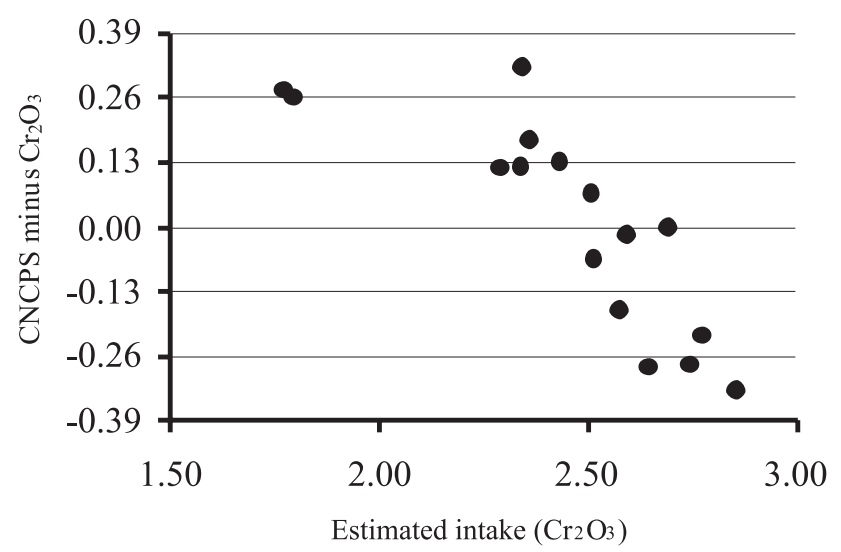

Figure 2 - Relationship between deviation (dry matter intake predicted by CNCPS minus estimated by chromium oxide technique) and values estimated by chromium oxide technique, indicating that $31.25 \%$ of the points are within the acceptable range $(-0.13$ a $0.13 \%$ body weight). 
Kolver et al. (1998) evaluated the CNCPSmodel (version 3.0) on DMI prediction and also reported the tendency of the model to underestimate the predicted DMI in Holstein cows. Lana \& Gomes Jr. (2002) studied the NRC (1996), levels 1 (NRC system) and 2 (Cornell System) in tropical conditions using growing beef cattle, and also obtained underestimated values for DMI in 12 and 13\%, respectively.

It is noteworthy that the model evaluation under grazing conditions must be conducted with caution, considering that under these conditions the actual consumption is unknown and can only be estimated using methodologies that may have errors.

The limited ability to measure or to predict the exact DMI values under grazing conditions is a factor of great interference in the development of suitable diets for the animals by these systems. There are many variables involved in the DMI regulation by grazing animals and, therefore, the interactions of the factors environment, animal (age, crossbred, physiological state, etc.) and changes in forage availability and quality (Lopes et al., 2003) must be considered, especially in tropical conditions.

Evaluating the CNCPS model on the prediction of milk production, the model underestimated $(\mathrm{P}<0.05)$ observed values, which presented a mean of $10.1 \mathrm{~kg} / \mathrm{cow} /$ day, while the predicted average output was $3.8 \mathrm{~kg} / \mathrm{day}$, a difference of $62.4 \%$. The mean bias obtained was significant by the t-test $(\mathrm{P}<0.05)$, demonstrating the inaccuracy of the model, confirmed by the high value of RMSPE (Table 4). The linear coefficient (intercept) of the regression did not differ ( $\mathrm{P}>0.05$ ) from zero, but the slope (slope) was different $(\mathrm{P}<0.05)$ from 1 , by the $t$ test (Table 4$)$. The regression presented a lack of model accuracy in the prediction of milk production, with different slope of the ideal straight line (X = Y; Figure 3). Analyzing the deviations (Figure 4), the proportion of points outside the acceptable limit was $100 \%$, reflecting the lack of model fit.

According to the model, the metabolizable energy (ME) requirements of animals were not met by the forage, being

Table 4 - Comparison between mean values of milk production observed and predicted by model

\begin{tabular}{|c|c|c|c|c|}
\hline & Milk production(kg/cow/day) & Mean bias (kg/cow/day) & Mean bias (\% predicted) & Standard deviation or RMSPE \\
\hline Observed $^{1}$ & 10.1 & 6.22 & 161.9 & 2.44 \\
\hline \multirow[t]{3}{*}{$\mathrm{CNCPS}^{2}$} & 3.8 & & & 6.41 \\
\hline & \multicolumn{4}{|c|}{ Regression $^{4}$} \\
\hline & Intercept & Slope & $\mathrm{R}^{2}$ & $\mathrm{P}$ \\
\hline Regular & 2.472 & 1.975 & 0.75 & $<0.001$ \\
\hline Origin $^{5}$ & - & 2.577 & 0.98 & $<0.001$ \\
\hline
\end{tabular}

1 Observed milk production.

2 Milk production predicted by CNCPS v.5.0.

3 Standard error for observed and root mean square prediction error (RMSPE) for predicted values (CNCPS).

${ }^{4}$ The estimated parameters of regression, intercept and slope, were evaluated by t-test $(0.05)$, for $\mathrm{B}_{0}=0$ and $\mathrm{B}_{1}=1$.

${ }^{5}$ Regression through the origin $\left(\mathrm{B}_{0}=0\right)$.

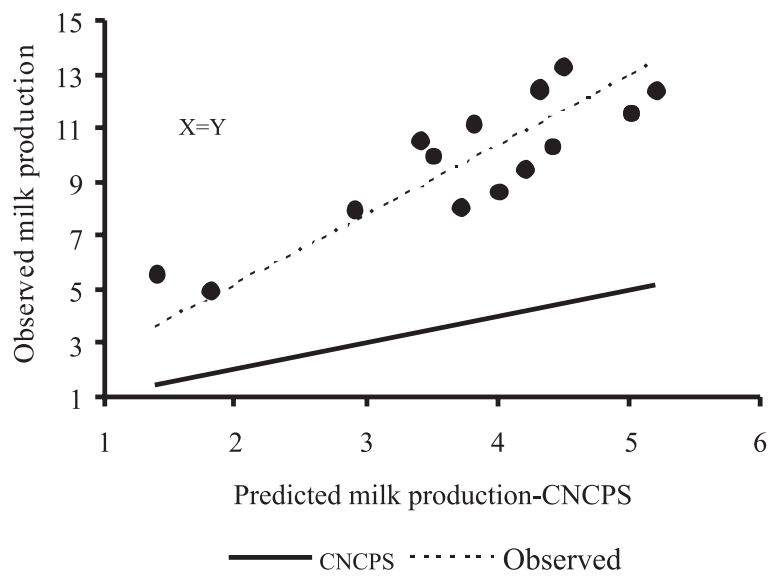

Figure 3 - Relation between milk production values (kg/cow/day) observed and predicted by CNCPS model.

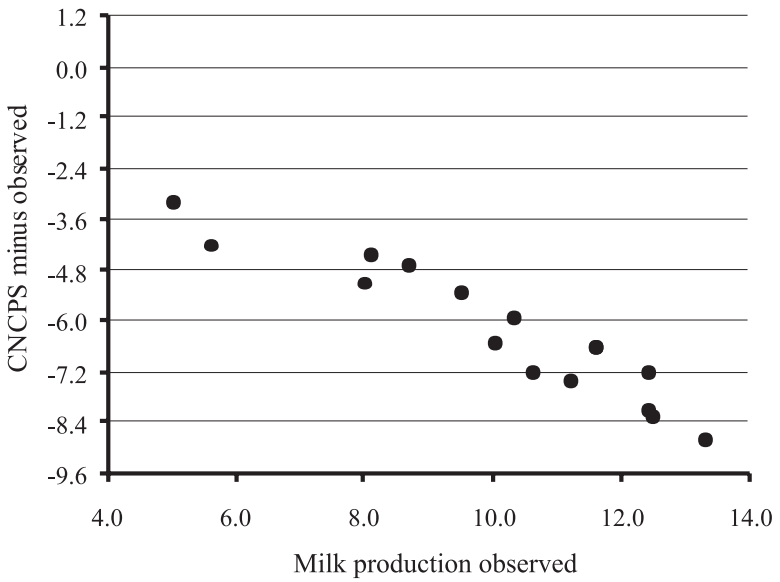

Figure 4 - Relation between deviations (milk production predicted by CNCPS minus observed) and observed values, indicating that $100 \%$ of the points are out of the acceptable range (-1.2 to $1.2 \mathrm{~kg} / \mathrm{cow} /$ day) 
the first limiting factor to milk production, where only $72.1 \%$ of the requirements were supplied by the diet, which contributed to the underestimation of observed production.

The time to lose 1 score body condition (14 days) and the loss of weight ( $243 \mathrm{~g} /$ day) predicted by the model were not observed during the experimental periods. However, there is no basis for discussing the validity of these estimates, given the short evaluation period.

Kolver et al. (1998) applied the CNCPS model in lactating cow fed grass as basal diet, and observed good model predictive ability on animal performance in these conditions. The authors also observed that the ME supply was the main limiting factor in milk production when animals were fed high quality forage (without concentrate) under intensive grazing system.

Cappelle et al. (2001) reported that the CNCPS model was not adequate in predicting weight gain in cattle. In contrast, Sampaio et al. (2001, 2002) and Brito et al. (2002), studying models of diet evaluation system in intensive beef cattle production, observed that CNCPS was efficient at predicting the performance of beef cattle. Similarly, Zhao et al. (2008) reported that the CNCPS model was efficient at average daily gain prediction in beef cattle, under production systems in China.

Lana \& Gomes Jr. (2002) evaluated the NRC system (1996) levels 1 (NRC system) and 2 (Cornell System) in tropical conditions and observed that, at both levels, the system underestimated the observed values for weight gain in growing grazing beef cattle, in the dry season. The estimated values were 55 and $85 \%$ lower than those observed for levels 1 and 2, respectively, where the Cornell system was the least accurate to estimate the observed weight gain values, demonstrating the lack of model fit for tropical conditions, especially to grazing animals.

An important point in the CNCPS model evaluation refers to the total digestible nutrients (TDN) values. According to CNCPS, TDN values of elephant grass were 44 and $45 \%$, for the first and second period, respectively. These values can be considered low when compared with IVDMD, which were 64.4 and 67.3\% in March and April, respectively. Deresz (2001) and Lopes (2002) reported similar values for IVDMD of elephant grass pasture at 30 days old. When the TDN was calculated using the equation proposed by Weiss et al. (1992), implemented in the NRC (2001), the values were 49.9 and $50.7 \%$ for the first and second period, respectively. However, Tedeschi et al. (2002) found similar TDN values estimated by CNCPS (level 2) and Weiss et al. (1992).
The lack of model fit to tropical forages may be related to the chemical composition, especially for the NDF and lignin contents, rather than to the digestion rates of nitrogen and carbohydrate fractions. Lagunes et al. (1999) and Fernandes et al. (2001) observed strong influence of the fiber fraction in the CNCPS prediction on the performance of lactating crossbred cows. The high fiber content is a marked characteristic of tropical forages, which contributes directly to the low quality of this forage (Van Soest, 1994). Therefore, it is important to establish the relations between fibrous carbohydrates (FC) and lignin contents with forage digestibility.

Furthermore, other factors that may have contributed to the lack of the model fit: 1) the method for obtaining samples of forage consumed, considering that the soluble carbohydrates of forage can be lost by saliva leaching during the extrusa collection (Hoehne et al., 1967). Clipes et al. (2005) and Lista et al. (2007) evaluated the effect of sampling method (extrusa versus hand-plucked samples) and observed higher levels of FC in extrusa samples of elephant grass cv. Napier, probably due to "loss" of part of the NFC in saliva drained from the collection bag. Thus, the fraction of FC and lignin could be overestimated, with consequent underestimation of forage quality; 2) the CNCPS model tends to overestimate the ruminal passage rate (kp) in grazing animals, the model predicted the average $\mathrm{kp}$ value of $0.035 / \mathrm{h}$, while the estimated using the NDFchromium-mordant, was $0.021 / \mathrm{h}$. The kp overestimating results in underestimation of the forage degradation in the reticulum-rumen compartment; 3) the interaction of the factors described above may have also contributed to the lower TDN values estimated by the model; and 4) the fact that the CNCPS estimates the nutritional requirements values using a factorial model - which, in most cases, results in linear response -, and with data from european breeds with production levels higher than those observed under pasture conditions in the tropics. This may contribute to the underestimation of the performance, because to estimate the nutritional requirements of low performance animals, the CNCPS extrapolates the factorial system to predict the nutritional requirements, with consequent overestimation of these values.

The development of a database concerning the chemical characteristics of tropical forages and foods, as well as the standardization of the methodology used to evaluate these foods, are the starting point for the development of studies to adjust the model to tropical conditions and allow its appropriate application. 


\section{Conclusions}

The Cornell Net Carbohydrate and Protein System was able to predict the dry matter intake of lactating crossbred cows accurately, although it was not effective in predicting milk production of these crossbred cows grazing elephant grass pasture under tropical conditions. The results show the need for studies that provide the model fit to the tropical conditions, for an appropriate application in diets and supplements formulation in these regions.

\section{References}

ASSOCIATION OF OFFICIAL ANALYTICAL CHEMISTS - AOAC. Official methods of analysis. 15.ed. Arlington, Virginia: 1990. v.1, 1117p.

BRITO, R.M.; SAMPAIO, A.A.M.; CRUZ, G.M. Comparação de sistemas para avaliação de dietas para bovinos no modelo de produção intensiva de carne. II - Creep feeding. Revista Brasileira de Zootecnia, v.31, n.2, p.1002-1010, 2002 (supl).

CAPPELLE, E.R.; VALADARES FILHO, S.C.; COELHO DA SILVA, J.F. et al. Estimativa do consumo e do ganho de peso de bovinos, em condições brasileiras. Revista Brasileira de Zootecnia, v.30, n.6, p.1857-1865, 2001.

CLIPES, R.C.; COELHO DA SILVA, J.F.; DETMANN, E. et al. Avaliação de métodos de amostragem em pastagens de capimelefante (Pennisetum purpureum, Schum) e capim-mombaça (Panicum maximum, Jacq) sob pastejo rotacionado. Arquivo Brasileiro de Medicina Veteterinária e Zootecnia, v.57, n.1, p.120-127, 2005.

CÓSER, A.C.; MARTINS, C.E.; DERESZ, F. et al. Métodos para estimar a forragem consumível em pastagem de capim-elefante. Pesquisa Agropecuária Brasileira, v.38, n.7, p.875-879, 2003.

DERESZ, F. Produção de leite de vacas mestiças Holandês x Zebu em pastagem de capim-elefante, manejada em sistema rotativo, com e sem suplementação na época das chuvas. Revista Brasileira de Zootecnia, v.30, n.1, p.197-204, 2001

ELYAS, A.C.W.; PAIVA, P.C.A.; LOPES, F.C.F. et al. Avaliação do modelo CNCPS na predição do consumo de matéria seca em vacas da raça Holandesa em pastejo. Revista Brasileira de Zootecnia, v.38, n.6, p.1096-1103, 2009.

FERNANDES, A.M.; QUEIROZ, A.C.; LANA, R.P. et al. Estimativas da produção de leite por vacas holandesas mestiças, segundo o sistema CNCPS, em dietas contendo cana-de-açúcar com diferentes valores nutritivos. Revista Brasileira de Zootecnia, v.30, n.4, p.1350-1357, 2001

FOX, D.G.; BARRY, M.C.; PITT, R.E. et al. Application of the Cornell net carbohydrate and protein model for cattle consuming forages. Journal of Animal Science, v.73, n.1, p.267-277, 1995.

FOX, D.G.; TEDESCHI, L.O.; TYLUTKI, T.P. et al. The Cornell Net Carbohydrate and Protein System model for evaluating herd nutrition and nutrient excretion. Animal Feed Science and Technology, v.112, p.29-78, 2004.

FOX, D.G.; TYLUTKI, T.P.; CZYMMEK, K.J. et al. Development and application of the Cornell University Nutrient Management Planning System. In: CORNELL. NUTR. CONF. FEED MANUF., 2000, Cornell University. Proceedings... Cornell, p.167-179, 2000.

GESUALDI JÚNIOR, A.; QUEIROZ, A.C.; RESENDE, F.D. et al. Validação dos sistemas Viçosa, CNCPS e NRC para formulação de dietas para bovinos Nelore e Caracu, não-castrados, selecionados em condições brasileiras. Revista Brasileira de Zootecnia, v.34, n.3, p.997-1005, 2005.
GROVUM, W.L.; WILLIAMS, V.J. Rate of passage of digesta in sheep. 4. Passage of marker through the alimentary tract and the biological relevance of rate-constants derived from the changes in concentration of marker in feces. British Journal of Nutrition, v.30, p.313-329, 1973.

HOEHNE, J.L.; ANDERSON, B.E.; KLOPFESTEIN, T.J. et al. Chemical changes in esophageal fistulas samples caused by salivar contamination and samples preparation. Journal of Animal Science, v.26, n.3, p.628-631, 1967.

KOLVER, E.S.; MULLER, L.D.; BARRY, M.C. et al. Evaluation and application of the Cornell Net Carbohydrate and Protein System for dairy cows fed diets based on pasture. Journal of Dairy Science, v.81, p.2029-2039, 1998.

LAGUNES, F.I.J.; FOX, D.G.; BLAKE, R.W. et al. Evaluation of tropical grasses for milk production by dual-purpose cows in tropical Mexico. Journal of Dairy Science, v.82, n.10, p.2136-2145, 1999.

LANA, R.P.; GOMES JÚNIOR, P. Sistema de suplementação alimentar para bovinos de corte em pastejo. Validação. Revista Brasileira de Zootecnia, vol.31, n.1, p.451-459, 2002 (supl.).

LICITRA, G., HERNANDEZ, T.M., VAN SOEST, P.J. Standardization of procedures for nitrogen fractionation of ruminant feeds. Animal Feed Science and Technology, v.57, p.347-358, 1996.

LISTA, F.N.; COELHO DA SILVA, J.F.; VÁSQUEZ, H.M. et al. Avaliação de métodos de amostragem qualitativa em pastagens tropicais manejadas em sistema rotacionado. Revista Brasileira de Zootecnia, v.36, n.5, p.1413-1418, 2007.

LOPES, F.C.F.; RODRIGUEZ, N.M.; AROEIRA, L.J.M. et al Modelagem comparativa da cinética de fluxo da fase sólida do capim-elefante (Pennisetum purpureum, Schumack) consumido sob pastejo por vacas mestiças Holandês $\times$ Zebu em lactação. Arquivo Brasileiro de Medicina Veterinária e Zootecnia, v.55, n.6, p.702-709, 2003.

LOPES, F.C.F. Taxa de passagem, digestibilidade in situ, consumo, composição química e disponibilidade do capim-elefante (Pennisetum purpureum, Schumack) pastejado por vacas mestiças Holandês x Zebu em lactação. 2002. 223f. Tese (Doutorado) - Universidade Federal de Minas Gerais, Belo Horizonte.

MOLINA, D.O.; MATAMOROS, I.; ALMEIDA, Z. et al. Evaluation of the dry matter intake predictions of the Cornell Net Carbohydrate and Protein System with Holstein and dualpurpose lactating cattle in the tropics. Animal Feed Science and Technology, v.114, p.261-278, 2004.

NATIONAL RESEARCH COUNCIL - NRC. Nutrient requirements of beef cattle. 7.ed. Washington, D.C.: National Academy Press, 1996. 242p.

NATIONAL RESEARCH COUNCIL - NRC. Nutrient requirements of dairy cattle. 7.ed. rev. Washington, DC: National Academy Press, 2001. 157p.

PELL, A.N.; SCHOFIELD, P. Computerized monitoring of gas production to measure forage digestion in vitro. Journal of Dairy Science, v.76, n.9, p.1063-1073, 1993.

POND, K.R.; ELLIS, W.C.; MATIS, J.H. et al. Passage of chromiummordanted and rare-earth-labeled fiber: time dosing kinetics. Journal of Animal Science, v.67, p.1020-1028, 1989.

SAMPAIO, A.A.M.; BRITO, R.M.; AGUIAR, L.L.M. et al. Comparação de sistemas para avaliação de dietas para bovinos no modelo de produção intensiva de carne. Suplementação do pasto para vacas na estação seca. Revista Brasileira de Zootecnia, v.30, n.4, p.1287-1292, 2001.

SAMPAIO, A.A.M.; BRITO, R.M.; CARVALHO, M.R. et al. Comparação de sistemas para avaliação de dietas para bovinos no modelo de produção intensiva de carne. Confinamento de tourinhos jovens. Revista Brasileira de Zootecnia, v.31, n.1, p.157-163, 2002.

SCHOFIELD, P.; PITT, R.E.; PELL, A.N. Kinetics of fiber digestion from in vitro gas production. Journal of Animal Science, v.72, p.2980-2991, 1994. 
SNIFFEN, C.J.; O’CONNOR, J.D.; VAN SOEST, P.J. et al. A net carbohydrate and protein system for evaluating cattle diets: II. Carbohydrate and protein availability. Journal of Animal Science, v.70, n.11, p.3562-3577, 1992.

TEDESCHI, L.O. Assessment of the adequacy of mathematical models. Agriculture Systems, v.89, p.225-247, 2006.

TEDESCHI, L.O.; FOX, D.G.; PELL, A.N. Development and evaluation of tropical feed library for the Cornell Net Carbohydrate and Protein System. Scientia agricola, v.59, n.1, p.1-18, 2002.

TEDESCHI, L.O.; FOX, D.G.; RUSSEL, J.B. Accounting for the effects of a ruminal nitrogen deficiency within the structure of the Cornell Net Carbohydrate and Protein System. Journal of Animal Science, v.78, p.1648-1658, 2000.

TEDESCHI, L.O.; FOX, D.G.; SAINZ, R.D. et al. Using mathematical models in ruminant nutrition. Scientia Agricola, v.62, p.76-91, 2005.

TILLEY, J.M.A.; TERRY, R.A. A two stages technique for the "in vitro" digestion of forage crops. Journal British of Grassland Society, v.18, n.1, p.104-111, 1963.

TRAXLER, M. J. Predicting the effect of lignin on the extent of digestion and evaluation of alternative intake models for lactating cows consuming high FDN forages. 1997. 145f. Dissertation (Doctor of Philosophy), Cornell University, Cornell.

VAN DYNE, G.M.; TORELL, D.T. Development and use of esophageal fistula: a review. Journal of Range Management, v.17, p.7-19, 1964.

VAN SOEST, P.J. Nutrition ecology of the ruminant. Ithaca: Comstock Publishing Associates, 1994. 476p.

VAN SOEST, P.J.; ROBERTSON, J.B.; LEWIS, B.A. Methods for dietary fiber, neutral detergent, and nonstarch polysaccharides in relation to animal nutrition. Journal of Dairy Science, v.74, n.10, p.3583-3597, 1991.

WEISS, W.P.; CONRAD, H.R.; ST. PIERRE, N.R. A theoreticallybased model for predicting total digestible nutrient values of forages and concentrates. Animal Feed Science and Technology, v.39, p.95-110, 1992.

WILLIAMS, C.H.; DAVID, D.J.; IISMAA, O. The determination of chromic oxide in feces samples by atomic absorption spectrophotometry. Journal of Agriculture Science, v.59, n.3, p.381-385, 1962.

ZHAO, J.S.; ZHOU, Z.M.; REN, L.P. et al. Evaluation of dry matter intake and daily weight gain predictions of the Cornell Net Carbohydrate and Protein System with local breeds of beef cattle in China. Animal Feed Science and Technology, v.142, p.231-246, 2008. 